\title{
SEED RESERVE COMPOSITION AND MOBILIZATION DURING GERMINATION AND INITIAL SEEDLING DEVELOPMENT OF Euphorbia heterophylla
}

\author{
CECILIA N.K. SUDA ${ }^{1}$ AND JARBAS F. GIORGINI ${ }^{2}$
}

Departamento de Biologia/Faculdade de Filosofia, Ciências e Letras de Ribeirão Preto/Universidade de São Paulo - Ribeirão Preto - SP

\begin{abstract}
Seed composition and reserve mobilization were investigated in wild poinsettia (Euphorbia heterophylla L.). Lipids, around $60 \%$ of seed dry mass, are the major reserve. Proteins, including albumins (49\%), salt insoluble globulins (30\%), salt-soluble globulins $(21 \%)$ and prolamins $(0.3 \%)$, comprise about a quarter of seed dry mass. Soluble sugars comprise about $3.6 \%$ of seed dry mass, sucrose being the predominant sugar. Starch was not detected in the endosperm of E. heterophylla. Lipid depletion starts after initial imbibition, and is completed between 72 and 96 hours. Protein fractions exhibit different degradation patterns, salt-soluble globulins being continuously degraded after the start of imbibition whereas salt insoluble fractions are degraded between 36 and 72 hours, and albumins between 60 and 84 hours. Globulin depletion is accompanied by an increase in free amino acids in the endosperm whereas intense albumin depletion is not. This result suggests that during albumin depletion there is a rapid transfer of amino acids to the growing embryo. Histochemical studies indicated that light accelerates protein degradation in the micropylar area of the seed. Soluble sugars increase in the embryo with no concomitant decrease in the endosperm, suggesting that sugars are mostly originated from the catabolism of lipids.
\end{abstract}

ADDITIONAL INDEX TERMS: Weed, wild poinsettia, Euphorbiaceae, proteins, lipids, carbohydrates.

\section{COMPOSIÇÃO E MOBILIZAÇÃO DE RESERVA DA SEMENTE DE Euphorbia heterophylla DURANTE A GERMINAÇÃO E DESENVOLVIMENTO INICIAL DA PLÂNTULA}

\begin{abstract}
RESUMO - A composição e a mobilização de reservas da semente de amendoim-bravo (Euphorbia heterophylla L.) foi investigada. Os lipídios constituem cerca de $60 \%$ da massa seca da semente, sendo o principal material de reserva. As proteínas constituem aproximadamente a quarta parte da massa seca da semente distribuídas entre as frações de albuminas (49\%), globulinas insolúveis (30\%), globulinas solúveis em solução salina $(21 \%)$ e prolaminas $(0,3 \%)$. Os açúcares solúveis constituem cerca de $3,6 \%$ da massa seca da semente, sendo a sacarose o açúcar predominante. $O$ amido não foi detectado no endosperma de E. heterophylla. A degradação dos lipídios inicia-se logo após a embebição inicial da

Received: 02/02/00 - Accepted: 10/10/00

1. Graduate student, Departamento de Bioquímica, Faculdade de Medicina de Ribeiro Preto, Universidade de São Paulo, Ribeirão Preto - SP, 14.049-900, Brasil. E-mail:cnksuda@usp.br

2. Corresponding author. E-mail: jarbas@ffclrp.usp.br
\end{abstract}


semente sendo completada entre 72 e 96 horas. As frações protéicas têm diferentes padrões de degradação: as globulinas solúveis são continuamente degradadas após o início da embebição da semente, as globulinas insolúveis entre 36 e 72 horas e as albuminas entre 60 e 84 horas. A degradação das globulinas é concomitante com o aumento nos níveis de aminoácidos no endosperma, mas a degradação de albuminas não é. Esse resultado sugere que durante a degradação de albuminas ocorre uma rápida transferência de aminoácidos do endosperma para o embrião. Estudos histoquímicos indicaram que a luz acelera a degradação das proteínas na região micropilar da semente. Os açúcares solúveis aumentam no embrião sem uma concomitante diminuição no esdosperma, sugerindo que os açúcares são originados do catabolismo de lipídios.

TERMOS ADICIONAIS PARA INDEXAÇÃO: Planta invasora, amendoim-bravo, Euphorbiaceae, proteínas, lipídios, carboidratos.

\section{INTRODUCTION}

Euphorbia heterophylla L. (wild poinsettia), a native plant of tropical and subtropical America (Hutchinson and Dalziel, 1958), is now widely spread as an important weed in at least 28 tropical countries and is present in 37 more (Wilson, 1981). In Brazil it has become a major weed mainly in soybean fields (Cerdeira et al., 1981; Lorenzi, 1982; Santos and Corso, 1986; Pinto and Panizzi, 1994; Barreto and Evans, 1998). In the United States it has been recognized as a major weed in soybean in Louisiana since the late 1970s (Bannon et al., 1978; Moore et al., 1990; Bridges et al., 1992; Willard and Griffin, 1993a, b; Brecke, 1995) and has continued to increase in distribution and prevalence during recent years. It is now considered a weed of major economic importance in both peanut and cotton in Georgia and Florida (Bridges et al., 1992).

Research on E. heterophylla has been mainly directed toward finding suitable methods for its control (Gusman et al., 1990; Moore et al., 1990; Willard and Griffin, 1993a, b; O'Makinwa and Akinyemiju, 1993; Brecke and Tobola, 1996). However, it has persisted as an agricultural problem probably resulting from widespread adoption of chemical weed control, coupled with the weed's resistance to most herbicides; high seed production and the fact that seed germination can occur at any time throughout the growing season (Egunjobi and Kupoluyi, 1973; Wilson, 1981; Barreto and Evans, 1998). The germination of $E$. heterophylla seed has been investigated (Bannon $e t$ al., 1978; Suda et al., 1989; Brecke, 1995; Suda and Pereira, 1997) but there is no information available on the physiological and biochemical aspects of reserve composition and mobilization in the seed.

The main purpose of the present work is to analyze lipids, proteins and carbohydrates in the endosperm of $E$. heterophylla during germination and initial seedling development and thus contribute to the knowledge on seed metabolism in this species.

\section{MATERIAL AND METHODS}

\section{Plant material}

Mature fruits of Euphorbia heterophylla L. were collected from local plants and dried until dehiscence; seeds were harvested by hand and stored in air-tight flasks at $5{ }^{\circ} \mathrm{C}$. At this temperature seeds remain viable for several months (Bannon et al., 1978); however, lots were renewed every 3 months for use in our experiments.

\section{Germination}

Seeds were germinated in 9-cm Petri dishes on two sheets of Whatman No. 1 filter paper moistened with distilled water $(3 \mathrm{~mL})$. The dishes were placed in a growth chamber at 25 or $30^{\circ} \mathrm{C}$ under continuous light or total darkness. For all biochemical analyses the seeds were germinated at $30{ }^{\circ} \mathrm{C}$. Darkness was maintained by wrapping the 
Petri dishes with black polyethylene. For germination tests three dishes, each containing 25 seeds, were used for each treatment. For the growth study and biochemical analyses, material was sampled from a large population of seeds or seedlings. Seed germination measurements under darkness were made in a light-proof room under a green safe-light. Germination was defined as elongation of the radicle to at least $5 \mathrm{~mm}$.

\section{Estimation of endosperm degradation and embryo growth}

At various times after imbibition, 15 seeds or seedlings were harvested and the embryo (cotyledons plus embryo-axis) separated from the endosperm. For cotyledon dry mass determination 20 pairs of cotyledons were excised from 20 embryos. Dry matter was determined by weighing the parts after a period until dry weight remained constant (at least $24 \mathrm{~h}$ at $80{ }^{\circ} \mathrm{C}$ ).

\section{Determination of chlorophyll}

Chlorophyll was determined using the method of Arnon (1949) after extracting the cotyledons with $80 \%$ acetone $(\mathrm{v} / \mathrm{v})$. Triplicate samples of 20 pairs of cotyledons were used for each determination.

\section{Determination of lipids, soluble sugars, proteins, amino acids and starch}

The seeds and seedlings were harvested and the parts were separated as described above. Triplicate samples of 20 endosperms or embryos were used for each determination.

For total lipid determination endosperm was ground in a mortar and pestle in $5 \mathrm{~mL}$ of chloroform:methanol $(2: 1, \mathrm{v} / \mathrm{v})$ and the next steps were carried out according to the procedure described by Becker et al. (1978), except that the combined organic phases were shaken with 0.1 mol. $\mathrm{L}^{-1} \mathrm{KCl}$, which permitted a better separation of the phases (Radin, 1969). All procedures were done at room temperature.

For soluble sugars and free amino acids determinations endosperms or embryos were ground in a mortar and pestle in $10 \mathrm{~mL}$ of $80 \%$ ethanol $(\mathrm{v} / \mathrm{v})$ and the mixture boiled for $10 \mathrm{~min}$. Following centrifugation at 2,000 $\mathrm{x} g$ for $10 \mathrm{~min}$, the supernatant was collected and the pellet reextracted in $10 \mathrm{~mL}$ of hot $80 \%$ ethanol. Supernatants from both extractions were combined, and total soluble sugar and reducing sugars were then determined by the phenol sulfuric acid (Dubois et al., 1956) and Nelson-Somogy (Somogy, 1952) methods, respectively, using glucose as standard. Free amino acids were determined in the final supernatant by the ninhydrin method (Moore and Stein, 1954) using leucine as standard. In some embryo supernatants chlorophyll removal was necessary before sugar or amino acid determinations. These supernatants were shaken with an equal volume of petroleum ether and, after phase separation, the chlorophyll containing phase (petroleum ether) was discarded and alcoholic phase used for determinations.

Proteins were extracted according to their solubility (García-Agustín and Primo-Millo, 1989) at $4{ }^{\circ} \mathrm{C}$. Endosperms were subjected to consecutive extraction with distilled water (albumins), 5\% $(\mathrm{w} / \mathrm{v})$ sodium chloride (globulins), $60 \% \quad(\mathrm{v} / \mathrm{v})$ ethanol (prolamins) and $0.4 \% \quad(\mathrm{w} / \mathrm{v})$ sodium hydroxide. The alkali-soluble protein, formerly named glutelin (Shewry and Tatham, 1990), is referred to in the present study as "salt insoluble protein". Extracts were centrifuged at 15,000 x $g$ for $2 \mathrm{~min}$ and the supernatant filtered. An aliquot of each extract was taken for the quantification of the proteins by the method of Lowry et al. (1951) using bovine serum albumin as the standard.

Starch was determined by the colorimetric method of Allen et al. (1974) which utilizes $\mathrm{KI}$ and $\mathrm{KIO}_{3}$.

\section{Determination of soluble sugars by thin-layer chromatography}

Sugar solutions $(1 \quad \mathrm{~mL})$ were concentrated at $30{ }^{\circ} \mathrm{C}$ during $24 \mathrm{~h}$ by evaporation of solvent ( $80 \%$ ethanol) and aliquots were spotted on silica-gel plates (Whatman, $250 \mu$ m layer).

Chromatography was performed according to the method of Lato et al. (1968) using 
a solvent system of n-buthanol-ethyl acetateisopropanol-acetic acid-water (7:20:12:7:6). Sugars were stained with naphthoresorcinol.

\section{Anatomical and histochemical analysis}

For observations under the light microscope, seeds were collected $0,24,48,72$, and 96 hours after the onset of imbibition. For lipids, seeds were sectioned $25-30 \mu \mathrm{m}$ thick with a freezing microtome and stained in oil red $\mathrm{O}$ (Cardemil and Reinero, 1982). Sections which were extracted with acetone were also stained with oil red $\mathrm{O}$, as control. For proteins, the seeds were fixed in FAA $(95 \%$ ethanol-acetic acidformaldehyde-water, 10:1:2:7). The seeds were dehydrated in a graded ethanol series and embedded in Paraplast. The sections $(25 \mu \mathrm{m})$ were stained with $0.25 \%(\mathrm{w} / \mathrm{v})$ Coomassie Blue $\mathrm{G}$ in $50 \%$ methanol (v/v) containing $10 \%(\mathrm{v} / \mathrm{v})$ acetic acid (Cawood et al., 1978).

\section{Gel electrophoresis of protein fractions}

Prior to electrophoresis, extracts of saltsoluble globulins and salt insoluble proteins were dialyzed against water and centrifuged at $15,000 \mathrm{x}$ $g$ for $2 \mathrm{~min}$. The pellet was resuspended in 62.5 mmol. $\mathrm{L}^{-1}$ Tris-HCl buffer ( $\mathrm{pH}$ 6.8) containing $2 \%$ $(\mathrm{w} / \mathrm{v})$ SDS, $10 \%(\mathrm{w} / \mathrm{v})$ glycerol, $5 \%(\mathrm{v} / \mathrm{v}) \beta-$ mercaptoethanol and $0.01 \%(\mathrm{w} / \mathrm{v})$ bromophenol blue and boiled for $90 \mathrm{~s}$. Albumin extracts were mixed with an equal volume of the above buffer twice concentrated.

Electrophoresis was carried out in $10 \%$ (w/v) SDS-polyacrylamide slab gels, according to the method of Laemmli (1970). Gels were stained with Coomassie Brilliant Blue G. The molecular masses of the proteins were estimated in relation to the mobilities of the molecular mass standard proteins (Dalton Mark VII-L, Sigma).

\section{RESULTS AND DISCUSSION}

The literature on light affecting the germination of E. heterophylla seeds is in some cases contradictory. Bannon et al. (1978) observed that light promotes germination when the seeds are maintained at constant temperatures. However, Brecke (1995) reported that the seeds are insensitive to light under the same conditions. Suda and Pereira (1997) showed that light sensitivity during germination in this species may be influenced both by the conditions in which the parent plants were grown and by the time interval during which seeds were stored. In the present work (Figure 1) light caused a highly significant increase in germination over the dark control. At $30{ }^{\circ} \mathrm{C}$ this difference became less apparent after 72 $\mathrm{h}$; however it was still significant even at $120 \mathrm{~h}$ as determined by Student $t$ test $(\mathrm{P}<0.05)$. The average germination time \pm confidence interval $(95 \%)$ was calculated according to Labouriau and Osborn (1984). At $30{ }^{\circ} \mathrm{C}$ under light or darkness mean germination times were $48.0 \pm 2.4$ or $74.4 \pm 21.6$ $\mathrm{h}$, respectively. At $25{ }^{\circ} \mathrm{C}$ under light, the mean germination time was $79.2 \pm 28.8 \mathrm{~h}$.

Table 1 summarizes the composition of E. heterophylla seeds. Lipids were the main reserve materials stored in the endosperm. Seeds of species belonging to the family Euphorbiaceae are usually rich in lipids (Rizk, 1987), e.g. castor-bean (Ricinus communis) seeds where the lipid content (Copeland and McDonald, 1995) approaches that found for E. heterophylla. According to Earle et al. (1960), linolenic and linoleic acids constitute the main fatty acids in E. heterophylla seeds.

Seed storage proteins were initially classified by Osborne (1924) according to their solubility into albumins (water soluble), globulins (saline soluble), prolamins (alcohol soluble) and glutelins (acid or alkali soluble). However, on the basis of currently available evidence, glutelins are now considered to be prolamins (Shewry and Tatham, 1990). The results from the sequential extraction procedure of proteins indicated that in $E$. heterophylla the albumins, the salt insoluble and the salt-soluble fractions comprised the major fraction, and prolamins accounted for only $0.3 \%$ of the seed protein. The salt-insoluble fraction could be dissolved in $0.1 \mathrm{~N} \mathrm{NaOH}$ or in the presence of SDS (sample buffer for SDS-PAGE). In this respect this fraction is similar to castor bean crystalloid protein (Tully and Beevers, 1976; 
Gifford et al., 1982). However, the protein from castor bean was also soluble in 0.37 mol. $\mathrm{L}^{-1} \mathrm{NaCl}$ (Youle and Huang, 1976) whereas the similar fraction from E. heterophylla was not, even using a more concentrated solution $\left(0.87\right.$ mol. $\left.\mathrm{L}^{-1} \mathrm{NaCl}\right)$. According to Gifford and Bewley (1983) and Lalonde et al. (1984) there are two major types within $11 \mathrm{~S}$ globulins: those which are soluble in salt solutions (e.g., legumins) and those which require the addition of urea or SDS for total solubility (e.g., crystalloids). Thus the insoluble protein of E. heterophylla seed may be included in the second group of globulins. The prolamin fraction is essentially absent in E. heterophylla seeds, confirming the idea that prolamins are restricted to one family, the grasses (Shewry et al., 1995).
The changes in dry matter of the endosperm and embryo (or seedling) are presented in Figure 2. In seeds maintained under light at 30 ${ }^{\circ} \mathrm{C}$ or $25{ }^{\circ} \mathrm{C}$ (Figure $2 \mathrm{~A}, \mathrm{C}$ ) or in the dark at $30{ }^{\circ} \mathrm{C}$ (Figure $2 \mathrm{~B}$ ), endosperm depletion occurred between 48 and $120 \mathrm{~h}$ from the start of imbibition with a concomitant increase in seedling dry matter. In seeds maintained under darkness at $25^{\circ} \mathrm{C}$, there was no significant variation in these parameters (Figure $2 \mathrm{D}$ ).

The changes in dry matter and chlorophyll content of the cotyledons of lightgrown seedlings are shown in Figure 3. There was an initial increase in dry matter between 48 and 72 $h$ followed by a slower increase thereafter. Chlorophyll content increased from $48 \mathrm{~h}$.

TABLE 1 - Composition of E. heterophylla endosperm. Percentage in relation to total protein in parentheses.

\begin{tabular}{lcc}
\hline \multicolumn{1}{c}{ Component } & Mass per Endosperm $^{\mathrm{a}}\left({\left.\mathrm{kg} \mathrm{x} 10^{-6}\right)}^{-}\right.$ & $\%$ of Dry Mass \\
\hline Lipid & $2.685 \pm 0.050$ & 59.0 \\
Protein fraction & & $13.2(48.5)$ \\
Albumin & $0.597 \pm 0.089$ & $8.1(30.2)$ \\
Salt insoluble & $0.372 \pm 0.013$ & $5.7(21.0)$ \\
Salt-soluble globulin & $0.258 \pm 0.036$ & $0.01(0.3)$ \\
Prolamin & $0.004 \pm 0.004$ & 27.0 \\
Total protein (sum of fractions) & & 3.7 \\
Soluble sugar & $0.166 \pm 0.002$ & \\
Starch & Not detected & \\
\hline
\end{tabular}

${ }^{a}$ Data expressed as mean \pm standard error.

${ }^{\mathrm{b}}$ Endosperm dry mass of quiescent seeds $=4.560 \pm 0.160 \mathrm{~kg} \mathrm{x} 10^{-6}$. 


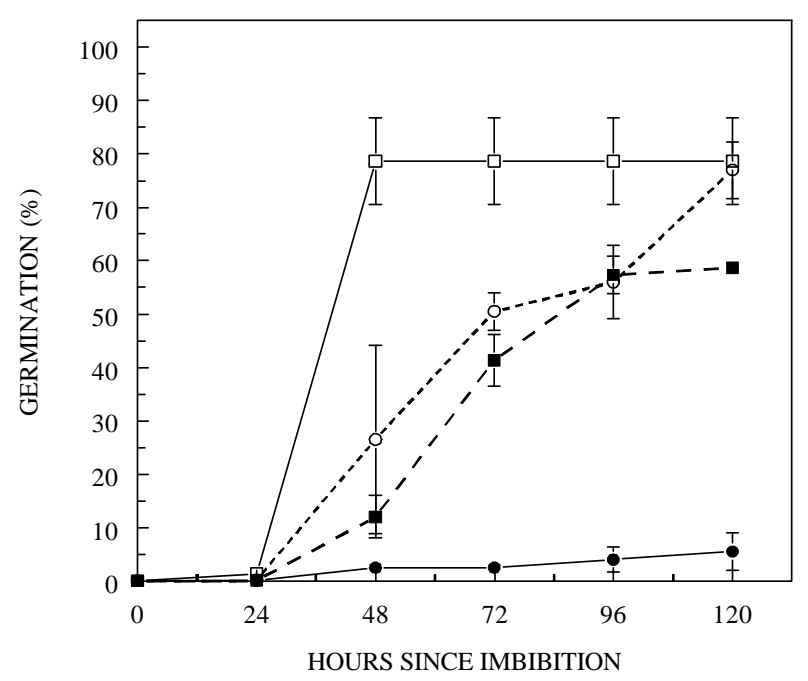

FIGURE 1 - Germination of E. heterophylla seeds at $25^{\circ} \mathrm{C}$ (circles) or $30^{\circ} \mathrm{C}$ (squares), under continuous white light (open symbols) or darkness (closed symbols). Each data point is a mean \pm standard error.

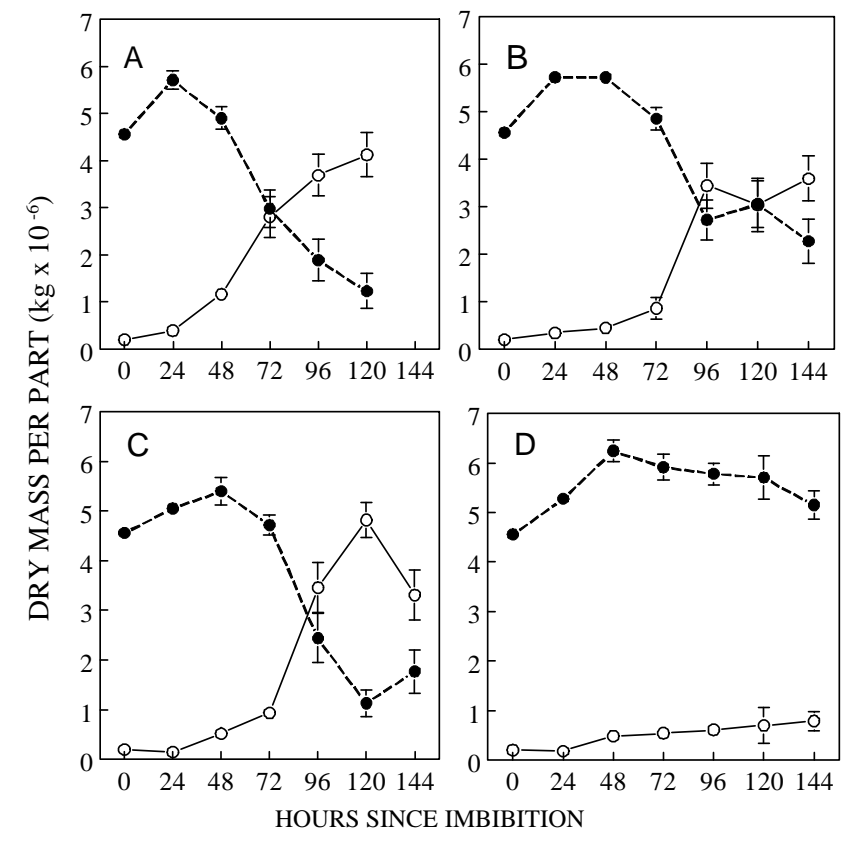

FIGURE 2 - Variation of dry mass of endosperm (closed symbol) and embryo (open symbol) during germination of E. heterophylla seeds. A, germination at $30^{\circ} \mathrm{C}$ under light; $\mathbf{B}, 30^{\circ} \mathrm{C}$ darkness; $\mathbf{C}, 25^{\circ} \mathrm{C}$ light; $\mathbf{D}, 25^{\circ} \mathrm{C}$ darkness. Each data point is a mean \pm standard error.

R. Bras. Fisiol. Veg., 12(3):226-245, 2000 


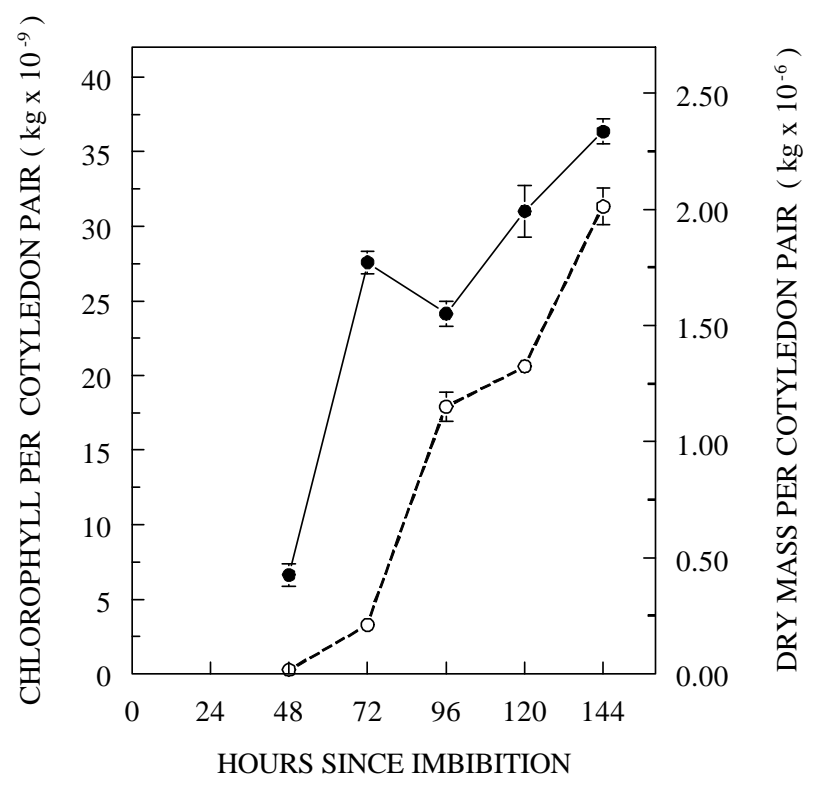

FIGURE 3 - Variation of dry mass (closed symbol) and chlorophyll (open symbol) of cotyledons during germination of E. heterophylla seeds at $30^{\circ} \mathrm{C}$ under light. Each data point is a mean \pm standard error.

Biochemical changes in the endosperm were investigated under light or darkness, at $30^{\circ} \mathrm{C}$. Degradation of stored lipids began immediately after imbibition (Figure 4). A rapid decline of the oil reserves was observed within 72 to $96 \mathrm{~h}$ in both dark and light-grown seedlings, when around $70 \%$ of the total lipids were digested. This pattern is unusual compared to some other oil rich seeds. In castor bean endosperm (Muto and Beevers, 1974), maize scutellum (Lin et al., 1983), and cucumber cotyledons (Slack et al., 1977; Becker et al., 1978), the total lipid content remained unchanged during early periods of germination but declined quickly thereafter.

The total sugar (Figure $5 \mathrm{~A}$ ) in the endosperm remained essentially constant up to 72 $\mathrm{h}$, declining thereafter. Reducing sugars (Figure 5 B) showed rapid increases until $48 \mathrm{~h}$ and declined sharply after $72 \mathrm{~h}$. In the embryo (Figure $5 \mathrm{C}, \mathrm{D}$ ) sugars increased after $36 \mathrm{~h}$. Chromatographic analysis of soluble sugars indicated that sucrose may be the major component of the free sugars fraction in the endosperm tissue (Figure $6 \mathrm{~A}$, lines 5 to 8 ). Glucose and fructose could be seen in these chromatograms, however, only in trace amounts. This may be not the case in the embryo after $48 \mathrm{~h}$ of imbibition, which presented apparently higher amounts of glucose and fructose (Figure $6 \mathrm{~B}$, lines 6 to 8). These results were also in agreement with the colorimetric analysis of sugars (Figure $5 \mathrm{D}$ ) where the embryos exhibited increasing amounts of reducing sugars after $48 \mathrm{~h}$. The correlation between the increase in reducing sugars and the appearance of glucose and fructose suggests that the hydrolysis of sucrose may be intense in the embryo over that period. In castor bean sucrose is the sugar actually transported from endosperm and hydrolysis occurs subsequently in tissues to which the sucrose is moved (Kriedemann and Beevers, 1967a,b). The total sugar level in the endosperm 




FIGURE 4 - Variation of lipids in endosperm during germination of E. heterophylla seeds at $30^{\circ} \mathrm{C}$ under light (open symbol) or darkness (closed symbol). Each data point is a mean \pm standard error.

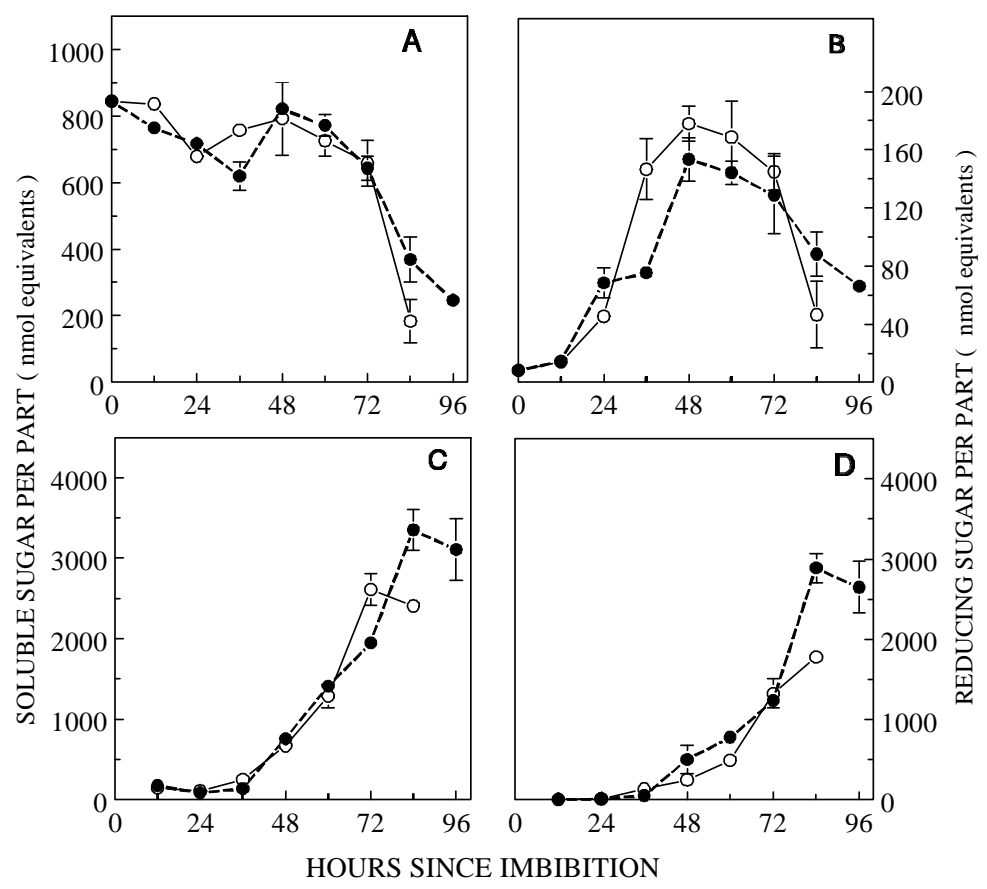

FIGURE 5 - Variation of total soluble and reducing sugars in endosperm and embryo during germination of E. heterophylla seeds at $30^{\circ} \mathrm{C}$ under light (open symbol) or darkness (closed symbol). A , soluble sugars in endosperm; $\mathbf{B}$, reducing sugars in endosperm; $\mathbf{C}$, soluble sugars in embryo; $\mathbf{D}$, reducing sugars in embryo. Each data point is a mean \pm standard error. 


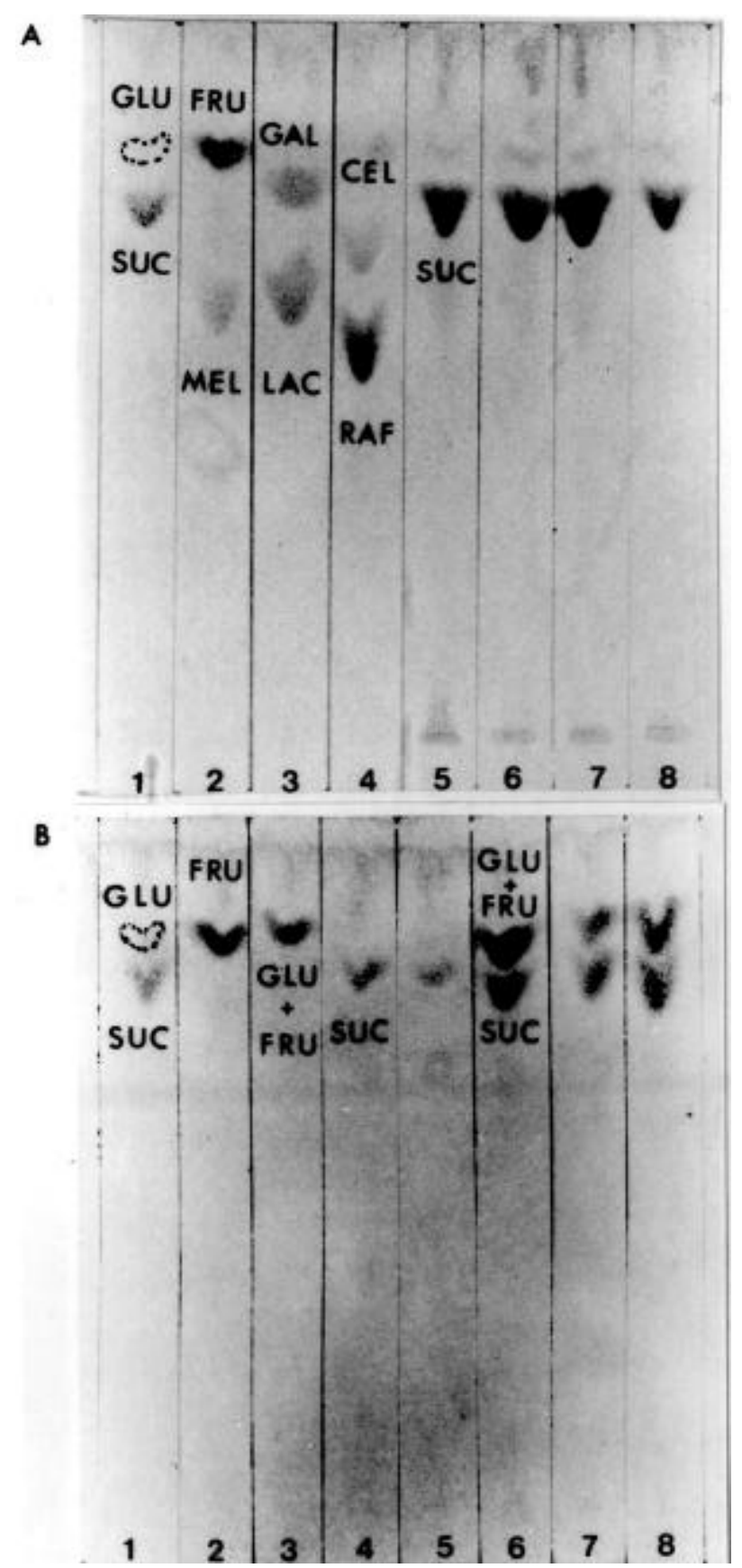

FIGURE 6 - Thin layer chromatogram of soluble sugars from endosperm (A) and embryo (B) during germination of E. heterophylla seeds at $30^{\circ} \mathrm{C}$ under light. A: 1-4, standard sugars: 1, glucose (faint spot) and sucrose; $\mathbf{2}$, fructose and melibiose; $\mathbf{3}$, galactose and lactose; $\mathbf{4}$, cellobiose and raffinose; $\mathbf{5 - 8}$, samples from different times since start of imbibition: 5, quiescent seeds; 6, $24 \mathrm{~h} ; \mathbf{7}, 48 \mathrm{~h}, \mathbf{8}, 72 \mathrm{~h}$. B: 1-3, standard sugars: 1, glucose (faint spot) and sucrose; $\mathbf{2}$, fructose; $\mathbf{3}$, glucose and fructose; $\mathbf{4 - 8}$, samples from different times after the start of imbibition: $\mathbf{4}, 12 \mathrm{~h} ; \mathbf{5}, 24 \mathrm{~h} ; \mathbf{6}, 48 \mathrm{~h} ; \mathbf{7}, 72 \mathrm{~h} ; \mathbf{8}, 96 \mathrm{~h}$. 
did not decrease when embryo sugar levels were increasing (Figure $5 \mathrm{~A}, \mathrm{C}$ ). Probably in the endosperm the conversion of stored lipids to carbohydrates occurred, maintaining sugar levels. This idea is supported by the fact that embryos also exhibit a similar increase in total sugar levels when seeds are maintained in the dark, and photosynthesis may then be excluded as the main source of sugars from the embryo. The conversion of reserve lipids to sugars has been extensively investigated in castor bean seeds (Kornberg and Beevers, 1957; Canvin and Beevers, 1961; Beevers, 1961). However, another source of sugar from the endosperm may be from amino acids derived from the breakdown of protein occurring at the same time. Gluconeogenesis from amino acids was demonstrated in germinating castor bean endosperm (Stewart and Beevers, 1967).
Starch and raffinose, which serve as reserve carbohydrates in a number of seeds (Bewley and Black, 1985), were not detected in E. heterophylla seeds (Table 1 and Figure $6 \mathrm{~A}$, lines 4 to 8 ). This finding is consistent with another study which indicated that another member of Euphorbiaceae, castor bean, does not contain raffinose (Amuti and Pollard, 1977).

Quantitative changes in the protein reserves are presented in Figure 7. The main periods of degradation occurred between 60 and 84 $\mathrm{h}$ for albumins and between 36 and $72 \mathrm{~h}$ for salt insoluble proteins when these fractions decreased respectively by $80 \%$ and $98 \%$ of their initial values. Salt-soluble globulins exhibited a slower decrease over the entire period.

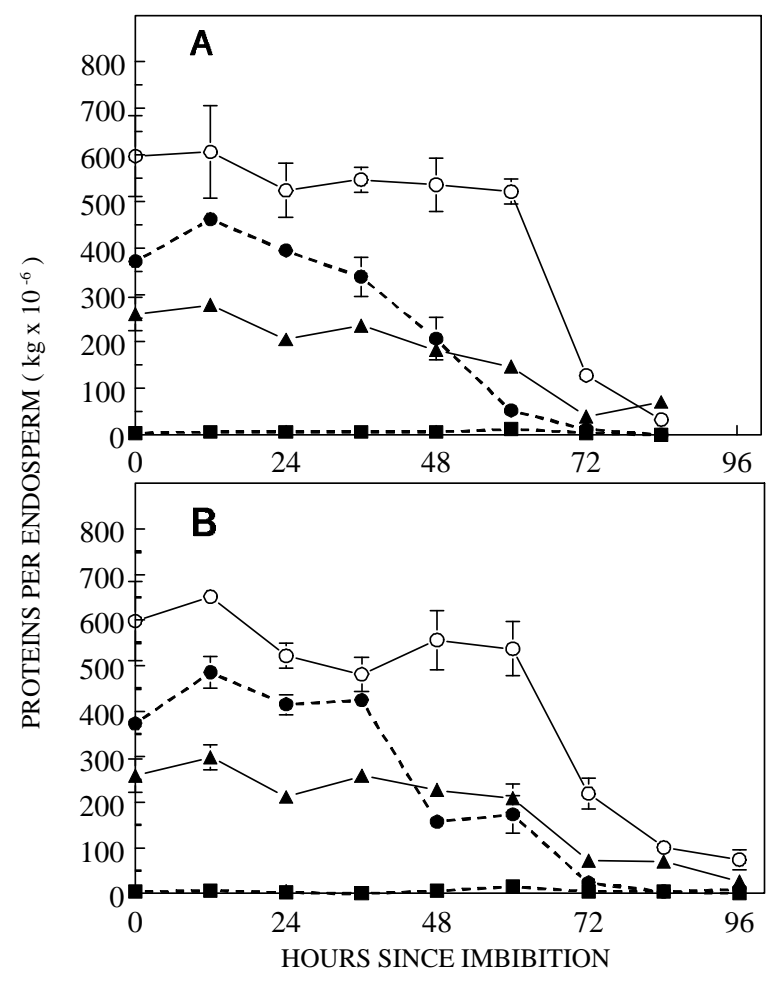

FIGURE 7 - Variation of protein fractions in endosperm during germination of E. heterophylla seeds at $30{ }^{\circ} \mathrm{C}$ under light (A) or darkness (B). Albumins, open circles; salt insoluble proteins, closed circles; saltsoluble globulins, closed triangles; prolamins, closed squares. Each data point is a mean \pm standard error. 
Electrophoretic profiles of endospermic protein fractions obtained from quiescent seeds at several periods after the start of imbibition are presented in Figure 8. The major bands of albumins exhibited molecular masses between 29.5 to $66 \mathrm{kDa}$ and 20 to $22 \mathrm{kDa}$; salt-soluble globulins between 43 to $47 \mathrm{kDa}, 31$ to $36 \mathrm{kDa}$ and 18 to 26 $\mathrm{kDa}$; salt insoluble proteins ranged between 29 to $36 \mathrm{kDa}$ and 18 to $20.5 \mathrm{kDa}$. Lalonde et al. (1984) reported for the insoluble protein (reduced form) from seeds of several Euphorbiaceae, including E. heterophylla, the predominance of two groups of polypeptides (20 to $25 \mathrm{kDa}$ and 29 to $35 \mathrm{kDa}$ ). The polypeptides between 20 to $25 \mathrm{kDa}$ were not prominent in our insoluble fraction (Figure 8) but were present in the salt-soluble fraction. This difference may be due to the methods of extraction since our insoluble fraction is the residue of high salt extraction which was included in our work as an additional step. Moreover, the molecular mass ranges obtained for $E$. heterophylla globulin subunits are in agreement with Marcone et al. (1998), who conducted detailed characterization of 21 purified seed globulins from dicotyledonous and monocotyledonous plants and concluded that the majority of subunits fell within two molecular mass ranges: 20 to $27 \mathrm{kDa}$ and 30 to $39 \mathrm{kDa}$. In addition, we observed that in the case of $E$. heterophylla the low molecular mass globulin subunits were found mainly in the salt-soluble fraction, whereas the high molecular mass subunits were found in both salt-soluble and insoluble fractions. After $48 \mathrm{~h}$ the albumin fraction exhibited a predominance of smaller polypeptides (around $20 \mathrm{kDa}$ ) (Figure 8). These results suggest that the albumin fraction may be subject to gradual hydrolysis in this process.
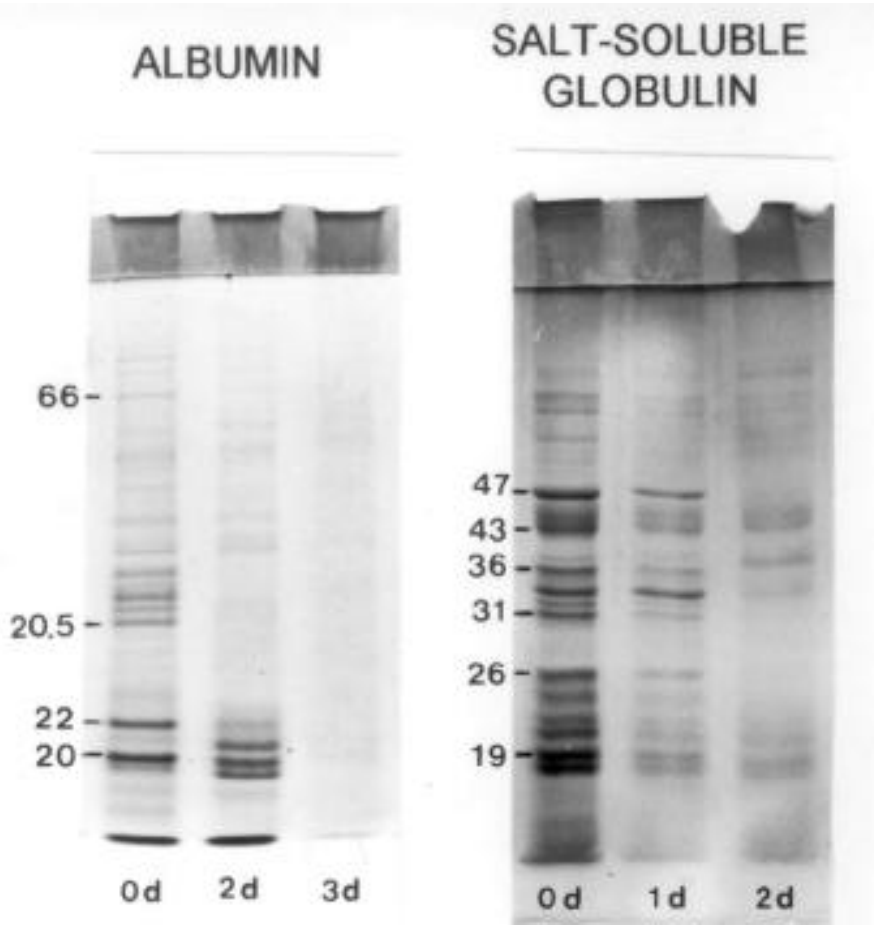

\section{SALT INSOLUBLE PROTEIN}

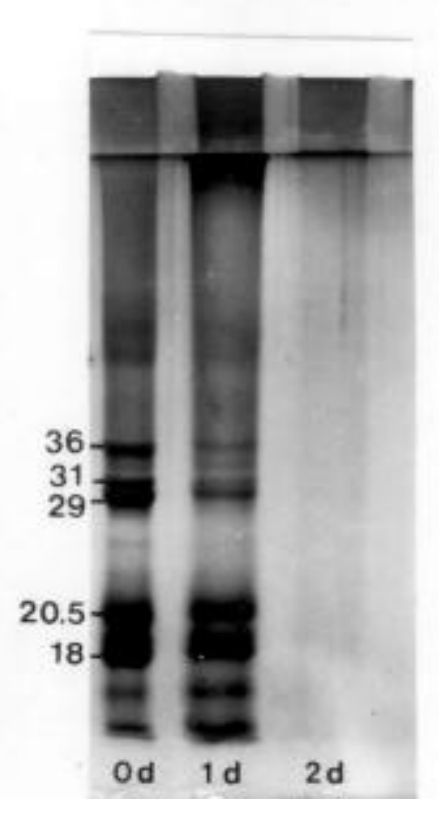

FIGURE 8 - SDS-PAGE profile of protein fractions of endosperm during germination of E. heterophylla seeds at $30^{\circ} \mathrm{C}$ under light. Protein fractions were extracted at different times after the start of imbibition. Molecular mass in kDa. 
Quantitative changes in free amino acids are presented in Figure 9. In the endosperm there was a peak between 24 and $60 \mathrm{~h}$ under light, and between 36 and $96 \mathrm{~h}$ under dark conditions. Most of the free amino acids which increase and accumulate in the endosperm (until $60 \mathrm{~h}$ under light or $72 \mathrm{~h}$ under darkness) may come from the degradation of globulins (salt-soluble and insoluble), since the amount of amino acids which are released by albumin degradation in this period may be low because limited proteolysis releases low amounts of amino acids (Müntz, 1996). In seeds maintained under light, the level of free amino acids rapidly decreased in the endosperm and simultaneously increased in the embryo over the period which coincided with the degradation of albumins (between 60 to $72 \mathrm{~h}$ ) (Figures 7 and 9). These results suggest that amino acids derived from albumins could be rapidly transferred from the endosperm into the embryo, owing to a source- sink relationship. The translocation in the dark was slower because the embryo could not be a fully active metabolic sink.

Histochemical analysis showed that lipid reserves in E. heterophylla endosperm are laid down in oil-bodies (Figure 10 A). The morphology of those bodies was modified $24 \mathrm{~h}$ after the onset of imbibition with swelling and apparent loss of integrity followed by their gradual disappearance (Figure $10 \mathrm{~B}$ ). These oil-bodies disappeared from the cells when the tissue was previously washed with acetone as control (not shown).

Sections from the endosperm of quiescent seeds exhibited protein bodies in abundance (Figure 11 A). Their fusion was observed at $24 \mathrm{~h}$ after the onset of seed imbibition, and their disappearance occurred gradually until 72 h (under light) (Figures 11 B, C, D) or 96 h (under darkness, not shown).

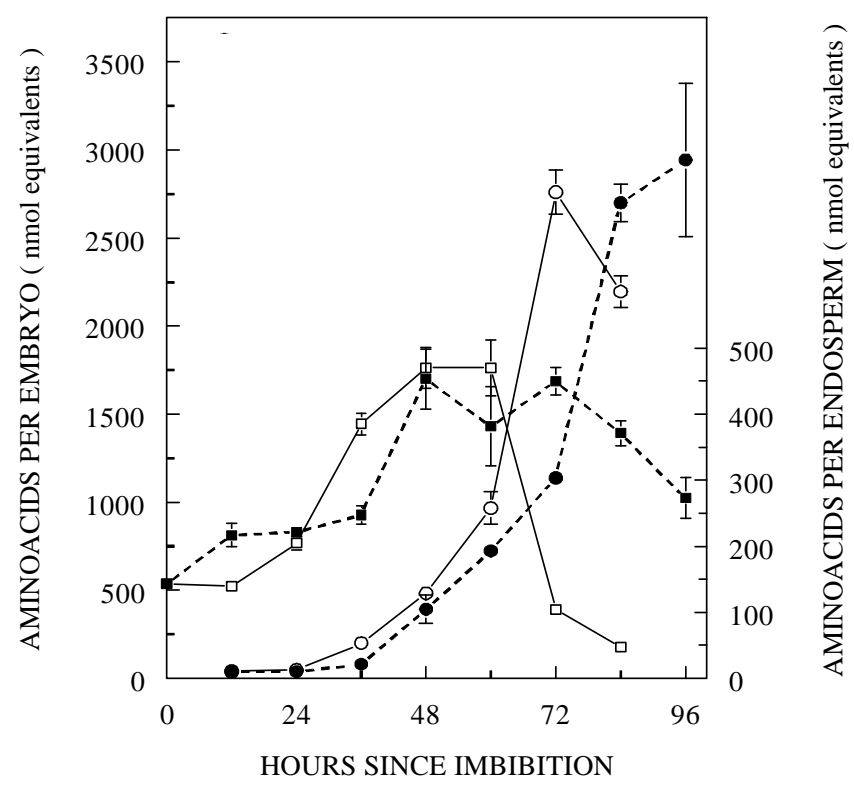

FIGURE 9 - Variation of free amino acids in endosperm (squares) and embryo (circles) during germination of $E$. heterophylla seeds at $30^{\circ} \mathrm{C}$ under light (open symbols) or darkness (closed symbols). Each data point is a mean \pm standard error. 


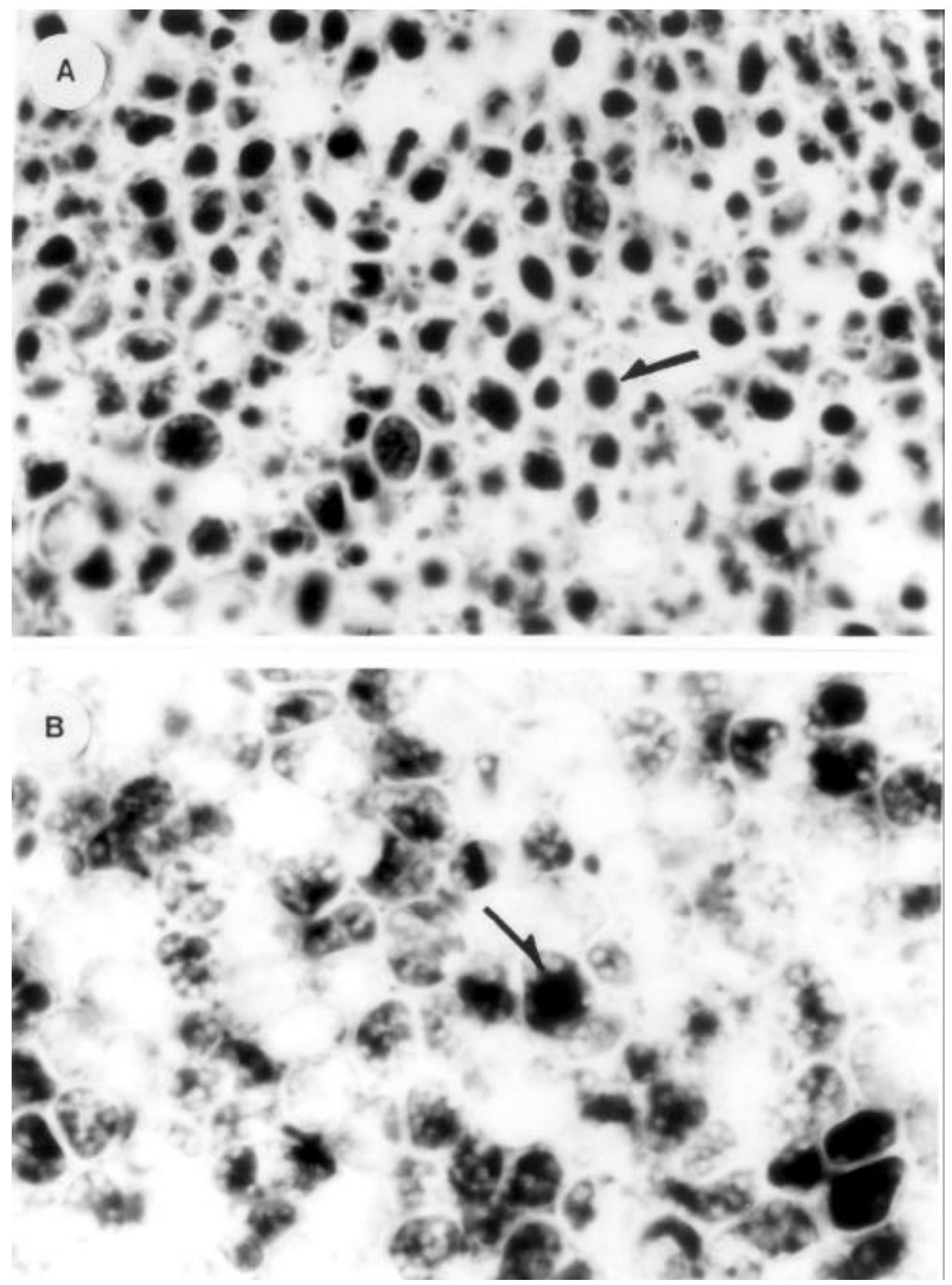

FIGURE 10 - Light micrographs showing oil bodies in the endosperm cells of E. heterophylla quiescent seed (A) and at $24 \mathrm{~h}$ after the start of imbibition at $30{ }^{\circ} \mathrm{C}$ under light $(\mathbf{B})$. Arrows indicate oil-bodies. Magnification x 311 . 

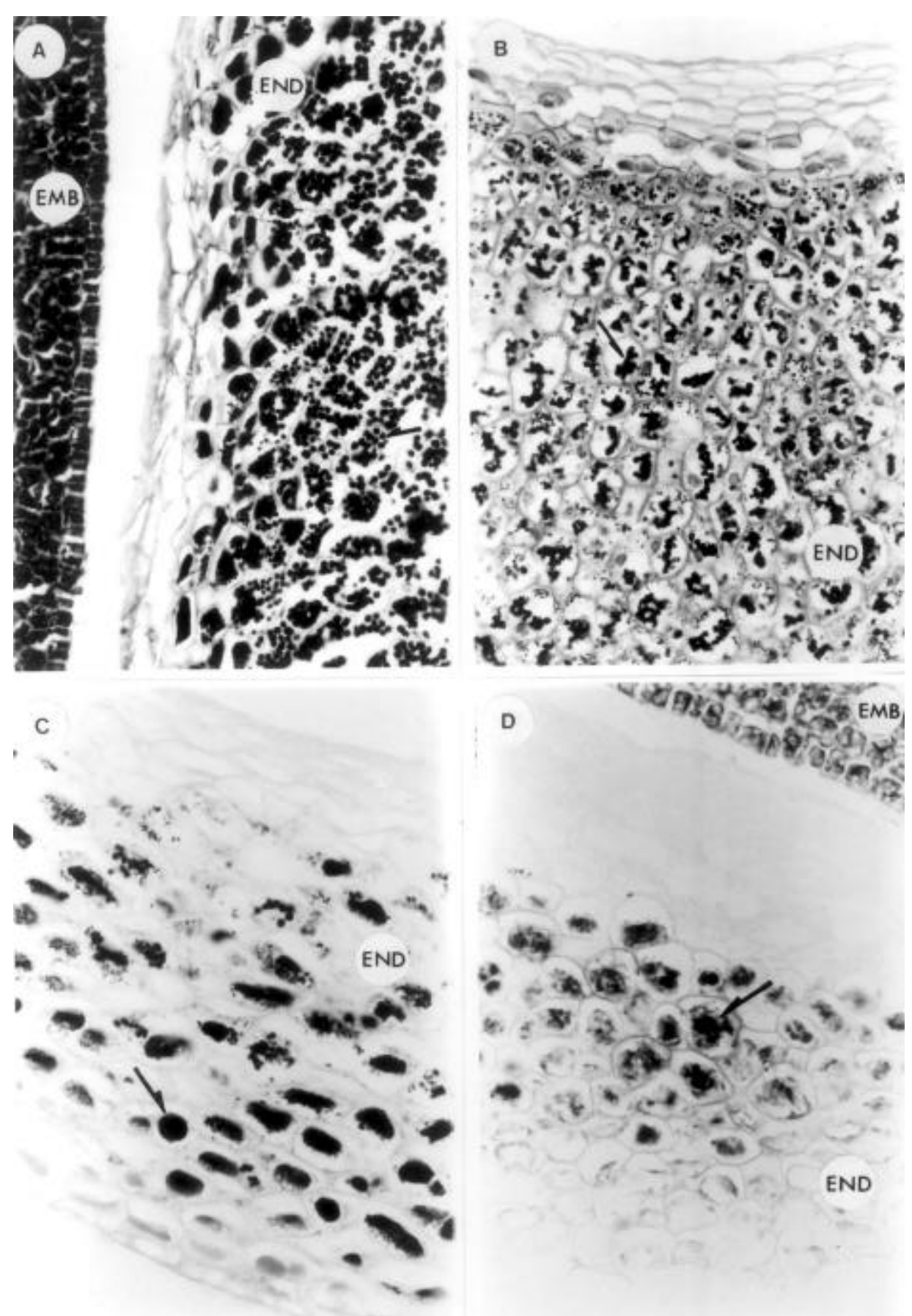

FIGURE 11 - Light micrographs showing protein bodies in the endosperm cells of E. heterophylla seeds. A, quiescent seed; B-D: at different times after the start of imbibition at $30{ }^{\circ} \mathrm{C}$ under light; $\mathbf{B}, 24 \mathrm{~h}$; $\mathbf{C} ; 48 \mathrm{~h} ; \mathbf{D} ; 72 \mathrm{~h}$. Arrows indicate protein bodies. END, endosperm; EMB, embryo. Magnification x 311. 


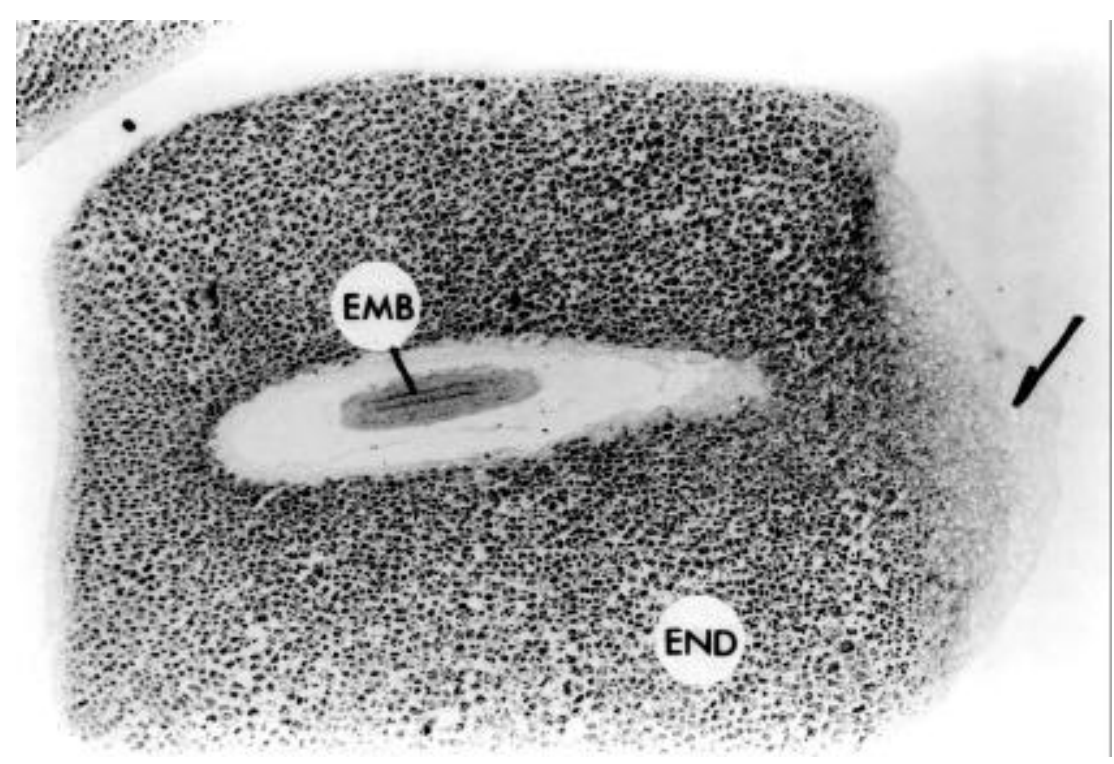

FIGURE 12 - Light micrographs showing reduction in protein body content in micropylar region (indicated by arrow) of endosperm of E. heterophylla. Longitudinal section of seed at $24 \mathrm{~h}$ after the start of imbibition at $30^{\circ} \mathrm{C}$ under light. END, endosperm; EMB, embryo. Magnification x 40.

Protein degradation in seed storage tissues during germination does not occur at once in the entire organ, the region where degradation starts varying according to species (Harris and Chrispeels, 1975; Harris et al., 1975; Davies and Chapman, 1981; Asghar and DeMason, 1990; Dias et al., 1993). In the present case, storage protein degradation was initiated in the micropylar region before emergence had occurred (Figure 12) and was accelerated by light. The disappearance of protein bodies occurred $24 \mathrm{~h}$ earlier in the light than in the dark (not shown). A similar phenomenon was observed in red light-treated lettuce (Lactuca sativa) achenes, where reserve materials of the micropylar end of the endosperm were mobilized prior to visible germination (Psaras et al., 1981).

The results presented here suggest that light may influence both degradation and translocation of reserves in the endosperm of $E$. heterophylla during germination and early seedling establishment. The observed decreases in dry mass were about $40 \%$ under light and about $20 \%$ under darkness between 48 and $72 \mathrm{~h}$ after the start of imbibition. Lipids, total protein and amino acids decreased over the same period at higher rates under light (about 47\%, 80\% and $77 \%$, respectively) when compared to the dark condition (about 20\%, 66\% and 1\%, respectively). On the other hand, decreases in total sugars and reducing sugars did not exhibit notable differences between light and dark germination conditions.

\section{ACKNOWLEDGEMENTS}

We thank Mr. Antônio J. Colusso, Mr. Marcelo Gonçalves, and Mr. Jaime L. Zeotti for technical assistance. We are grateful to Dr. João K. Kajiwara, Departamento de Morfologia, Faculdade de Medicina de Ribeirão Preto, Universidade de São Paulo for suggestions with respect to histochemical detection of lipid bodies. This work was partially supported by grants 92/3176-4 and 
96/8069-2 to JFG, Fundação de Amparo à Pesquisa do Estado de São Paulo.

\section{REFERENCES}

ALLEN, S.E.; GRIMSHAW H.M.; PARKINSON, J.A. \& QUARMBY, C. Chemical analysis of ecological materials. Oxford, Blackwell Scientific Publications, 1974. 565p.

AMUTI K.S. \& POLLARD C.J. Soluble carbohydrates of dry and developing seeds. Phytochemistry, 16: 529-532,1977.

ARNON, D.I. Copper enzymes in isolated chloroplasts. Polyphenoloxidase in Beta vulgaris. Plant Physiology, 24: 1-14, 1949.

ASGHAR, R. \& DEMASON, D.A. Developmental changes in the cotyledons of Lupinus luteus $\mathrm{L}$. during and after germination. American Journal of Botany, 77: 1342-1353, 1990.

BANNON, J.S.; BAKER J.B. \& ROGERS, R.L. Germination of wild poinsettia (Euphorbia heterophylla). Weed Science, 26: 221-225, 1978.

BARRETO, R.W. \& EVANS, H.C. Fungal pathogens of Euphorbia heterophylla and E. hirta in Brazil and their potential as weed biocontrol agents. Mycopathologia, 141: 2136, 1998.

BECKER, W.M.; LEAVER, C.J.; WEIR, E.M. \& RIEZMAN, H. Regulation of glyoxysomal enzymes during germination of cucumber. 1 . Developmental changes in cotyledonary protein, RNA, and enzyme activities during germination. Plant Physiology, 62: 542-549, 1978.

BEEVERS, H. Metabolic production of sucrose from fat. Nature, 191: 433-436, 1961.

BEWLEY, J.D. \& BLACK, M. Seeds: Physiology of Development and germination. New York, Plenum Press, 1985. 367p.
BRECKE, B.J. Wild poinsettia (Euphorbia heterophylla) germination and emergence. Weed Science, 43: 103-106, 1995.

BRECKE, B.J. \& TOBOLA, P. Growth and development of wild poinsettia (Euphorbia heterophylla) selections in peanut (Arachis hypogaea). Weed Science, 44: 575-578, 1996.

BRIDGES, D.C.; BRECKE, B.J. \& BARBOUR, J.C. Wild poinsettia (Euphorbia heterophylla) interference with peanut (Arachis hypogaea). Weed Science, 40: 37-42, 1992.

CANVIN, D.T. \& BEEVERS, H. Sucrose synthesis from acetate in the germinating castor bean: kinetics and pathway. Journal of Biological Chemistry, 236: 988-995, 1961.

CARDEMIL, L. \& REINERO, A. Changes of Araucaria araucana seed reserves during germination and early seedling growth. Canadian Journal of Botany, 60: 1629-1638, 1982.

CAWOOD, A.H.; POTTER, U. \& DICKINSON, H.G. An evaluation of Coomassie Brilliant Blue as a stain for quantitative microdensitometry of protein in section. Journal of Histochemistry and Cytochemistry, 26: 645-650, 1978.

CERDEIRA, A.L.; ROESSING, A.C. \& VOLL, E. Controle integrado de plantas daninhas em soja. Circular Técnica, 4. Londrina, EMBRAPA/CNPSO, 1981. 47p.

COPELAND, L.O. \& MCDONALD, M.B. Seed Science and Technology. (3rd edition) New York, Chapman \& Hall ,1995.

DAVIES, H.V. \& CHAPMAN, J.M. The control of food mobilization in seeds of Cucumis sativus L. 4. The pattern of protein degradation. Zeitschrift für Pflanzenphysiologie, 101: 347-353, 1981. 
DIAS, P.; WILSON, K.A. \& TAN-WILSON, A.L. Immunocytochemical analysis of proteolysis in germinating soybean. Phytochemistry, 33: 961-968, 1993.

DUBOIS, M.; GILLES, K.A.; HAMILTON, J.K.; REBERS, P.A. \& SMITH, F. Colorimetric method for determination of sugars and related substances. Analytical Chemistry, 28: 350356, 1956.

EARLE, F.R.; MCGUIRE, T.A.; MALLAN, J., BAGBY; M.O., WOLFF, I.A. \& JONES, Q. Search for new industrial oils. II. Oils with high iodine values. Journal of the American Oil Chemists' Society, 37: 48-50, 1960.

EGUNJOBI, J.K. \& KUPOLUYI, A.O. Studies on Nigerian weeds. 1. Biology and control of Euphorbia heterophylla L. In: PROCEEDINGS OF THE THIRD NIGERIAN WEED SCIENCE GROUP MEETING. Samaru (Nigeria), Institute of Agricultural Research, 1973, p. 42-46.

GARCÍA-AGUSTÍN, P. \& PRIMO-MILLO, E. Ultrastructural and biochemical changes in cotyledon reserve tissues during germination of Citrus seeds. Journal of Experimental Botany, 40: 383-390, 1989.

GIFFORD, D.J.; GREENWOOD, J.S. \& BEWLEY, J.D. Deposition of matrix and crystalloid storage proteins during protein body development in the endosperm of Ricinus communis L. cv. Hale. Plant Physiology, 69: 1471-1478, 1982.

GIFFORD, D.J. \& BEWLEY, J.D. An analysis of the subunit structure of the crystalloid protein complex from castor bean endosperm. Plant Physiology, 72: 376-381, 1983.

GUSMAN, A.B.; MUCILLO, G. \& PIRES, M.H. Efeito do citronelol sobre a germinação e desenvolvimento do amendoim-bravo
(Euphorbia heterophylla L.). Semina, 11: 2024, 1990.

HARRIS, N. \& CHRISPEELS, M.J. Histochemical and biochemical observations on storage protein metabolism and protein body autolysis in cotyledons of germinating mung beans. Plant Physiology, 56: 292-299, 1975.

HARRIS, N.; CHRISPEELS, M.J. \& BOULTER, D. Biochemical and histochemical studies on protease activity and reserve protein metabolism in the cotyledons of germinating cowpeas (Vigna unguiculata). Journal of Experimental Botany, 26: 544-554, 1975.

HUTCHINSON, J. \& DALZIEL, J.M. Flora of West Tropical Africa, Vol 1 (ii) (2nd edition, revised by KEAY, R.W.J., 1973). London, Crown Agents for Overseas Governments and Administrations, 1958, p. 297-828.

KORNBERG, H.L. \& BEEVERS, H. The glyoxylate cycle as a stage in the conversion of fat to carbohydrate in castor beans. Biochimica et Biophysica Acta, 26: 531-537, 1957.

KRIEDEMANN, P. \& BEEVERS, H. Sugar uptake and translocation in the castor bean seedling. I. Characteristics of transfer in intact and excised seedlings. Plant Physiology, 42: 161-173, 1967a.

KRIEDEMANN, P. \& BEEVERS, H. Sugar uptake and translocation in the castor bean seedling. II. Sugar transformations during uptake. Plant Physiology, 42: 174-180, 1967b.

LABOURIAU, L. G. \& OSBORN, J.H Temperature dependence of the germination of tomato seeds. Journal of Thermal Biology, 9: 285-294, 1984.

LAEMMLI, U.K. Cleavage of structural proteins during the assembly of the head bacteriophage $\mathrm{T}_{4}$. Nature, 227: 680-685 1970. 
LALONDE, L; FOUNTAIN, D.W.; KERMODE, A.; OUELLETTE, F.B.; SCOTT, K.; BEWLEY, J.D. \& GIFFORD, D.J. A comparative study of the insoluble storage proteins and the lectins of seeds of the Euphorbiaceae. Canadian Journal of Botany, 62: 1671-1677, 1984.

LATO, M.; BRUNELLI, B.; CIUFFINI, G. \& MEZZETTI, T. Analysis of carbohydrates in biological fluids by means of thin layer chromatography. Journal of Chromatography, 36: 191-197, 1968.

LIN Y.-H.; WIMER, L.T. \& HUANG, A.H.C. Lipase in the lipid bodies of corn scutella during seedling growth. Plant Physiology, 73: 460-463, 1983.

LORENZI, H. Plantas Daninhas do Brasil: Terrestres, Aquáticas, Parasitas, Tóxicas e Medicinais. Nova Odessa, published by the author, 1982. 425p.

LOWRY O.H.; ROSEBROUGH N.J.; FARR, A.L. \& RANDALL, R.J. Protein measurement with folin phenol reagent. Journal of Biological Chemistry, 193: 265-275, 1951.

MARCONE, M.F.; KAKUDA, Y. \& YADA, R.Y. Salt-soluble seed globulins of various dicotyledonous and monocotyledonous plants I. Isolation/purification and characterization. Food Chemistry, 62: 27-47, 1998.

MOORE, J.D.; BANKS, P.A. \& PINNELLALISON, C.L. Wild poinsettia (Euphorbia heterophylla) control in peanut (Arachis hypogaea). Weed Science, 38: 536-540, 1990.

MOORE, S. \& STEIN, W.H. A modified ninhydrin reagent for the photometric determination of amino acids and related compounds. Journal of Biological Chemistry, 211: 907-913, 1954.
MÜNTZ, K. Proteases and proteolytic cleavage of storage proteins in developing and germinating dicotyledonous seeds. Journal of Experimental Botany, 47: 605-622, 1996.

MUTO, S. \& BEEVERS H. Lipase activities in castor bean endosperm during germination. Plant Physiology, 54: 23-28, 1974.

O'MAKINWA, R.O. \& AKINYEMIJU, O.A. The influence of some herbicides on the control of Euphorbia heterophylla L. in cowpea. Malaysian Agricultural Journal, 54: 182194, 1993.

OSBORNE, T.B. The Vegetable Proteins. London, Longmans, Green and Co., 1924.

PINTO, S.B. \& PANIZZI, A.R. Performance of nymphal and adult Euschistus heros (F.) on milkweed and on soybean and effects of food switch on adult survivorship, reproduction and weight gain. Anais da Sociedade Entomológica do Brasil, 23: 549-555, 1994.

PSARAS, G.; GEORGHIOU, K. \& MITRAKOS, K. Red-light-induced endosperm preparation for radicle protrusion of lettuce embryos. Botanical Gazette, 142: 13-18, 1981.

RADIN, N.S. Preparation of lipid extracts. In: LOWENSTEIN, J.M. (Ed.) Methods in Enzymology, New York, Academic Press, 1969, v. 14, p. 245-254.

RIZK, A.-F.M. The chemical constituents and economic plants of the Euphorbiaceae. Botanical Journal of the Linnean Society, 94: 293-326, 1987.

SANTOS, D.M.M. DOS \& CORSO, G.M. Germinação, pré-plantio, pré-mergência e pósemergência de Euphorbia heterophylla L. (amendoim-bravo) sob a influência do Diuron. In: CONGRESSO DA SOCIEDADE 
BOTÂNICA DE SÃO PAULO, 6, Campinas, 1986. Anais, p. 59-65.

SHEWRY, P.R.\&TATHAM, A.S. The prolamin storage proteins of cereal seeds: structure and evolution. Biochemical Journal,267:1-12, 1990.

SHEWRY, P.R.; NAPIER, J.A. \& TATHAM, A.S. Seed storage proteins: structure and biosynthesis. Plant Cell, 7: 945-956, 1995.

SLACK, P. T.; BLACK, M. \& CHAPMAN, J.M. The control of lipid mobilization in Cucumis cotyledons. Journal of Experimental Botany, 28: 569-577, 1977.

SOMOGY, M. Notes on sugar determination. Journal of Biological Chemistry, 195:19-23, 1952.

STEWART, C.R. \& BEEVERS, H. Gluconeogenesis from amino acids in germinating castor bean endosperm and its role in transport to the embryo. Plant Physiology, 42: 1587-1595, 1967.

SUDA, C.N.K.; GIORGINI, J.F. \& GUSMAN, A.B. Ação inibidora do CEPA (ácido 2cloroetilfosfônico) sobre a germinação de sementes de Euphorbia heterophylla L. Acta Botanica Brasilica, 2: 97-102 (supl.), 1989.

SUDA, C.N.K. \& PEREIRA, M.F.D.A. Sensibilidade à luz de sementes de Euphorbia heterophylla L. durante a germinação. Revista
Brasileira de Fisiologia Vegetal, 9(1): 61-66, 1997.

TULLY, R.E. \& BEEVERS, H. Protein bodies of castor bean endosperm. Isolation, fractionation, and the characterization of protein components. Plant Physiology, 58: 710-716, 1976.

WILLARD, T.S. \& GRIFFIN, J.L. Soybean (Glycine max) yield and quality responses associated with wild poinsettia (Euphorbia heterophylla) control programs. Weed Technology, 7: 118-122, 1993a.

WILLARD, T.S. \& GRIFFIN, J.L. Growth response of wild poinsettia (Euphorbia heterophylla) following foliar herbicide applications. Weed Technology, 7: 190-195, 1993b.

WILSON, A. K. Euphorbia heterophylla: a review of distribution, importance and control. Tropical Pest Management, 27: 3238, 1981.

YOULE, R.J. \& HUANG, A.H.C. Protein bodies from the endosperm of castor bean. Subfractionation, protein components, lectins, and changes during germination. Plant Physiology, 58: 703-709, 1976. 